\title{
Beyond Bedlam: How Consumers and Brands Alike Are Playing the Web
}

\section{Citation}

Deighton, John A., and Leora Kornfeld. "Beyond Bedlam: How Consumers and Brands Alike Are Playing the Web." GfK Marketing Intelligence Review 6, no. 2 (November 2014): 28-33.

\section{Published Version}

http://www.degruyter.com/view/j/gfkmir.2014.6.issue-2/gfkmir-2014-0095/

gfkmir-2014-0095.xml

\section{Permanent link}

http://nrs.harvard.edu/urn-3:HUL.InstRepos:14485589

\section{Terms of Use}

This article was downloaded from Harvard University's DASH repository, and is made available under the terms and conditions applicable to Open Access Policy Articles, as set forth at http:// nrs.harvard.edu/urn-3:HUL.InstRepos:dash.current.terms-of-use\#OAP

\section{Share Your Story}

The Harvard community has made this article openly available.

Please share how this access benefits you. Submit a story.

Accessibility 


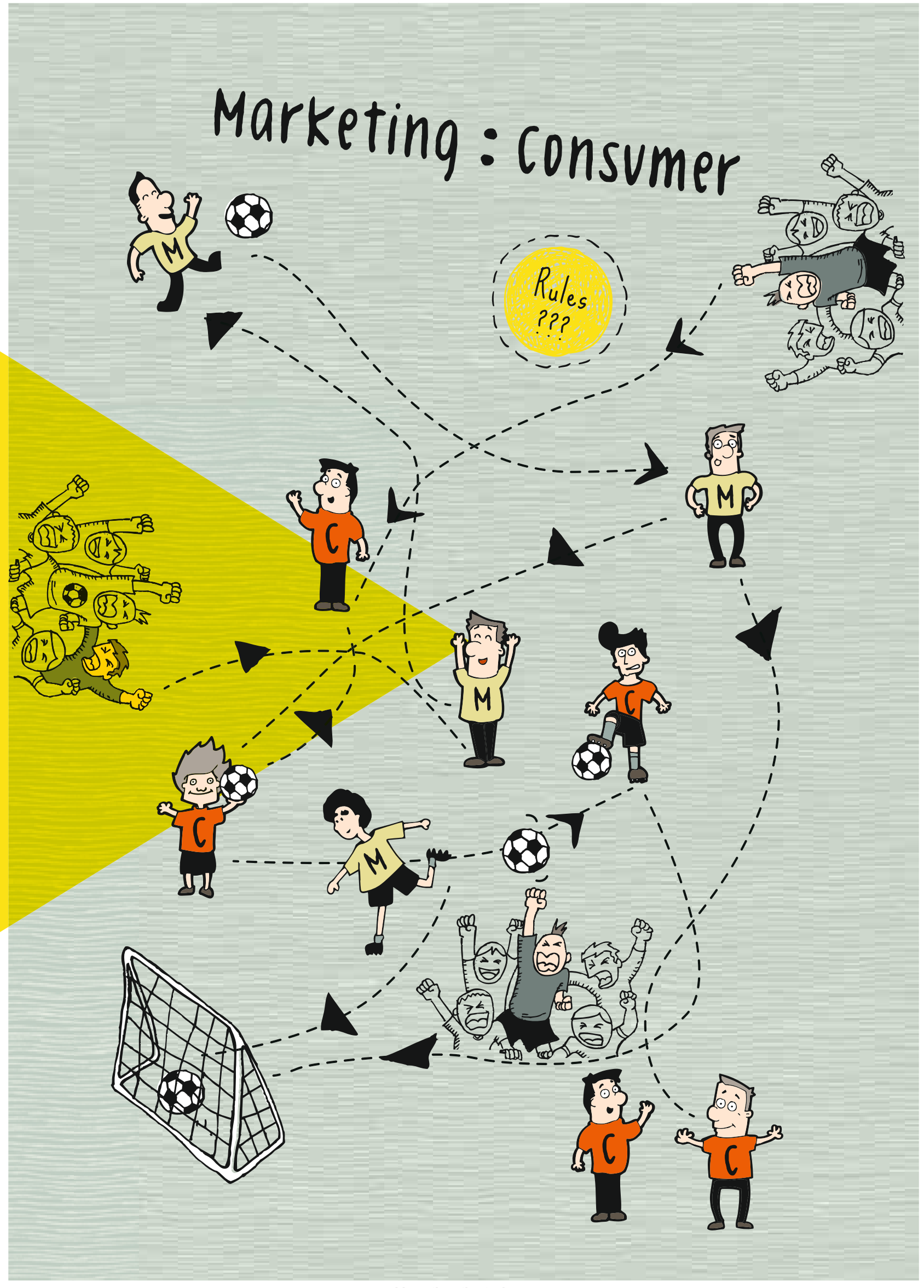




\title{
Beyond Bedlam: How Consumers and Brands Alike Are Playing the Web
}

\author{
John Deighton and Leora Kornfeld
}

KEYWORDS

Interactivity, Social Media,

Brands, Consumer Participation, Social Brand Engagement

THE AUTHORS

John Deighton,

Harold M. Brierley Professor of Business Administration, Harvard Business School, jdeighton@hbs.edu

Twitter: @HBSmktg

Leora Kornfeld, Digital Media Researcher, leora.kornfeld@gmail.com

Twitter: @LK617

Blog: www.demassed.blogspot.com
The new marketing order, as played out on media platforms like YouTube, Twitter and Instagram, is so unlike the order it is displacing that it might seem like bedlam, an asylum of sorts for ideas intelligible only to their creators. And yet, surely, something systematic is going on. It must have purpose; all the vigorous uploading, posting, commenting, and sharing must be generating results. We claim that the new order is, in fact, rule-governed, and the rules are the rules of play.

\section{Play as the Organizing Principle of Online Activity}

The word "play" has many contradictory meanings and forms. One plays to win, or just the opposite, to idle away the time. Some play is rule-bound, and some - in the form of playfulness - ignores the rules. Players can be tricksters, or they can be sincere. Play can be collaborative, or, when one plays into the other's hands, it becomes adversarial. But in every case, play implies intentional interaction and to turntaking. That is true even in solitary play, when one takes turns with a machine or interacts with facets of oneself.

So, play is our word for the tomfoolery of much of the current online activity: Interaction is present in all of it. And turntaking, or at least engagement between the communicator and the communicated-with, is a feature of each case. We can see shades of intent, from benign to exploitative. Now we will take a look at some of the consumer-marketer games in the context of digital marketing. 
Playing against /// Sometimes one player plays against the other. The relationship, for example, between a marketer with a message to deliver and a consumer wanting to be left alone, is often a little adversarial, and it is necessary to resort to subterfuge to gain attention. There is no subterfuge in conventional ads: They announce their own arrival. On television, the flow of a program is typically suspended and a cluster of six or eight ads is inserted into the break. On social media, on the other hand, the ad attacks are less straightforward, more playful and paradoxical, and it is not always clear what is actually being advertised. Consider a stunt by Nathan Fielder, a performer best known for his television show "Nathan For You", broadcast on the Comedy Central channel in the U.S., to see paradox at work.

When marketers use the Web to play against expectations and defenses, they build their audiences slowly, not borrowing the attention given to programming, but drawing people to the content itself. Once the audience is assembled, self-contradiction begins to dawn - we are attending the event, but the event is unworthy of our attention. A resolution of the contradiction is sought, from which the resolving fact is advertised.

Playing with /// Sometimes marketers and consumers play with each other instead of against each other. Straightforward collaboration is common in marketing, as when lkea asks consumers to assemble their own furniture or store promotions rely on shoppers to collect coupons. The play element in collaboration becomes possible because social media and interactive technologies enable collaboration to emerge spontaneously, often, in fact, without design or intention. Two examples of this concept are outlined in the case studies on this page: The LAY'S $\circledast$ Do Us A Flavor ${ }^{T M}$ contest illustrates this kind of momentum, while the singer Pharrell Williams' unusual oversized hat demonstrates a relatively complex case of play, with elements of deliberate intention as well as opportunism.

The "playing with" frame can take various forms. Consumers played with the Lay's contest. It is unlikely that Lay's intended to place the resources for such extensive brand bricolage in the hands of the public, but consumers are playful and used their chance. Arby's played with Pharrell's hat. Repartee in the background of live broadcast cannot be planned, but it can really charm audiences.

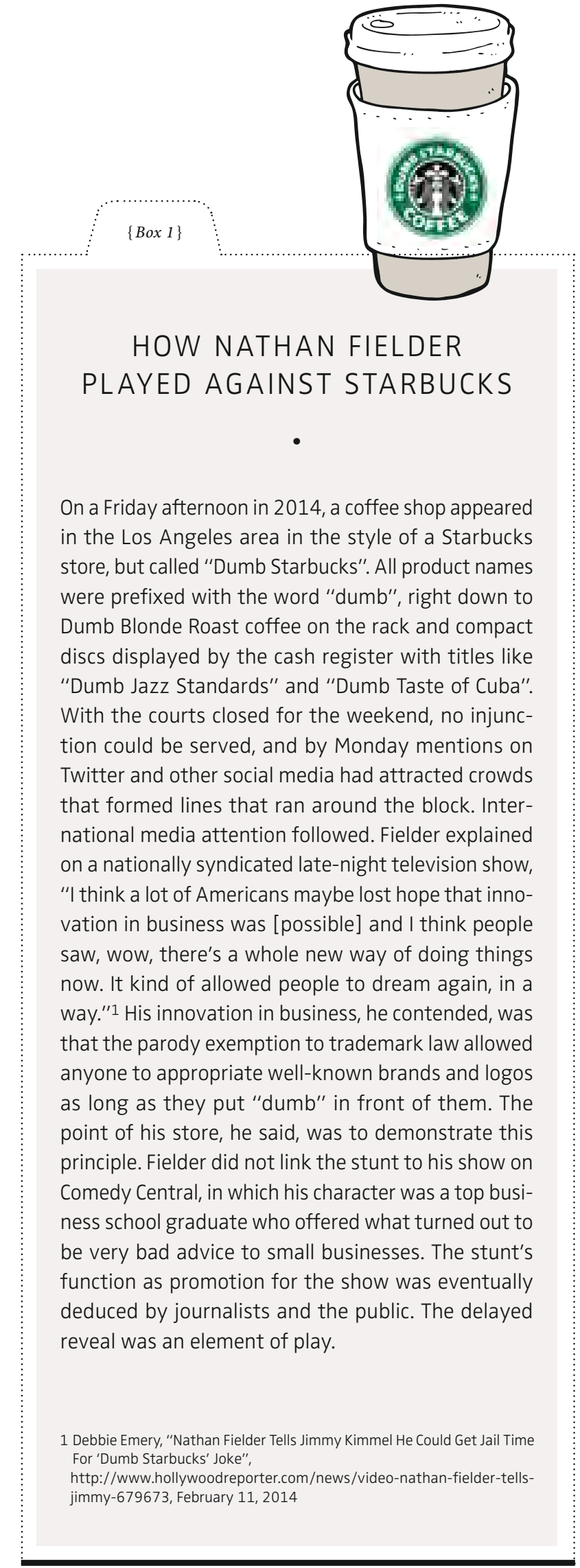




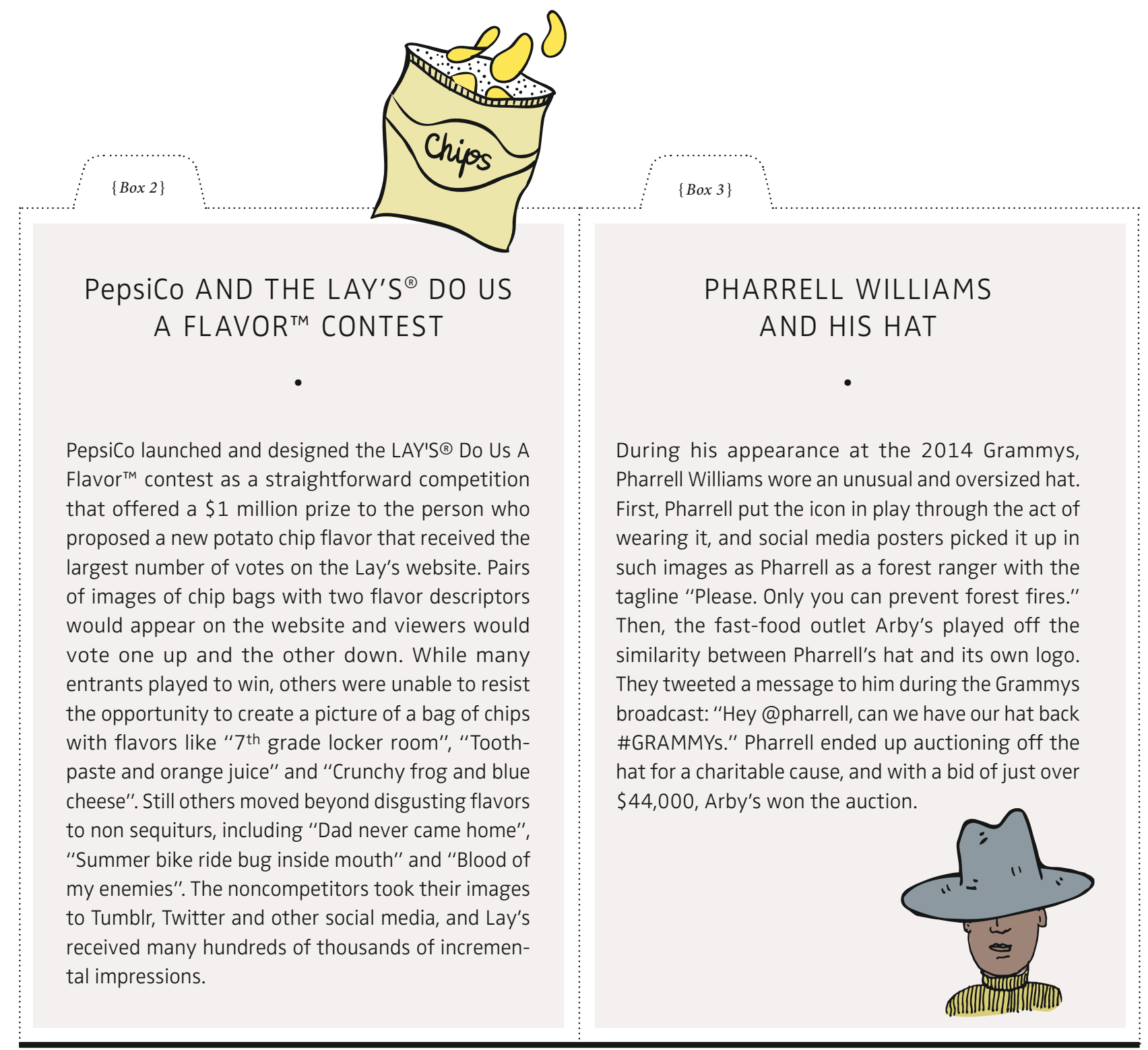

In some instances, brands even commit "intentional fouls" by deliberately making an error or releasing a misleading statement for the sake of a spike in online discussion and the mainstream-media coverage likely to follow. With varying degrees of success, the brands reveal, subsequent to the publicity, that their statements had been intended as stunts. When brands play with their consumers, some in the industry think that they are taking playfulness too far. Old-school commandand-control marketing strategists believe the gap between playfulness and incompetence is territory that brands should never visit. But strategists in the new marketing order break this rule because that is where they find the energy that fuels their markets.
Playing with play /// Sometimes play exploits ambiguity of form just as, in a Mobius strip, it is unclear where things begin, which surface is to be read as facing up, and which is to be understood as facing down. This kind of play with form has been found in a few notable videos posted on YouTube recently, such as the one for the HUVrboard. Sometimes posted with one intention and interpreted with another meaning, play becomes an interplay of genres and categories.

Just days after the HUVrboard video made the rounds, another video began to circulate on social media, with even greater force. It showed strangers kissing, and had a wistful and nostalgic feel. It seemed innocent yet sentimental, voyeuristic yet 
$\{$ Box 4$\}$

\section{BACK TO THE FUTURE: THE REAL HOVERBOARD}

In the first week of March 2014, a new company posted a video for a product called HUVrboard, featuring skateboarding legend Tony Hawk and Christopher Lloyd, the actor that played Emmett "Doc" Brown in the hit "Back to the Future" movies in the 1980s. The video showed Hawk demonstrating a skateboard that allowed the rider to remain suspended in the air for an extended period, similar to the hover board ridden by Michael J. Fox's character in "Back to the Future". Viewers couldn't believe their eyes, yet they were so exhilarated by what they saw and so convinced by Hawk's performance that they began tweeting, posting on Facebook and sharing the video at a frantic pace. The video received 12 million views in just a few days. Then came the follow-up video, an apology from Hawk, in which he admitted that the video had been a prank and misleading. He stated "This was not a promotion for a new movie or videogame, nor did I get paid (unrelated: I am releasing a game for mobile devices relatively soon). My reward was riding in a DeLorean with Doc, and pretending to be a stuntman."2 YouTube comedy channel "Funny or Die" later took credit for the stunt. Was it comedy for the sake of comedy? Was it an ad for "Funny or Die"? For Tony Hawk? For Christopher Lloyd? For something we'll find out about later?

2 Tony Maglio, "Funny or Die behind Tony Hawk, Christopher Lloyd Hoverboard Hoax", http://www.thewrap.com/funny-or-die-hoverboard-huvrtech-tony-hawk-christopher-Ilyod, March 5, 2014 real, and within a few days it had received 25 million views on YouTube. And then, as often happens with videos at first thought to be authentically "viral", it was revealed to be an ad for the fashion house Wren. Wren's founder, Melissa Coker, claimed to have had no plan for the video to propagate the way it did.

Often, there is no single answer, but we do know that attention, that most precious of commodities, had been seized, and in the loop that is digital marketing, that can be enough to proclaim victory.

Who's Playing Whom? /// In play, the actor makes moves that are calculated to produce an effect. Sometimes the effect is constructive, but sometimes it seems quite the oppo- site. What is Rob Ford, controversial and ubiquitous mayor of Toronto, playing at? The resources of YouTube and camera phones have made him arguably the best-known mayor in North America. There is no reason at all to pose for a "selfie" photograph with the average mayor; with Ford the shot goes to Instagram and Facebook and Twitter, and in the process amplifies Ford's name recognition thousandfold, while buying cachet for the person who posts it. Whether he is re-elected or not, he has won that most elusive brand status, iconicity.

But playfulness is of the essence. When Boston Red Sox's David Ortiz took a selfie with President Obama it seemed playful until it emerged that Ortiz was acting on behalf of Samsung cameras. Then the soft edge of play was displaced by the hard edge of a trick. 


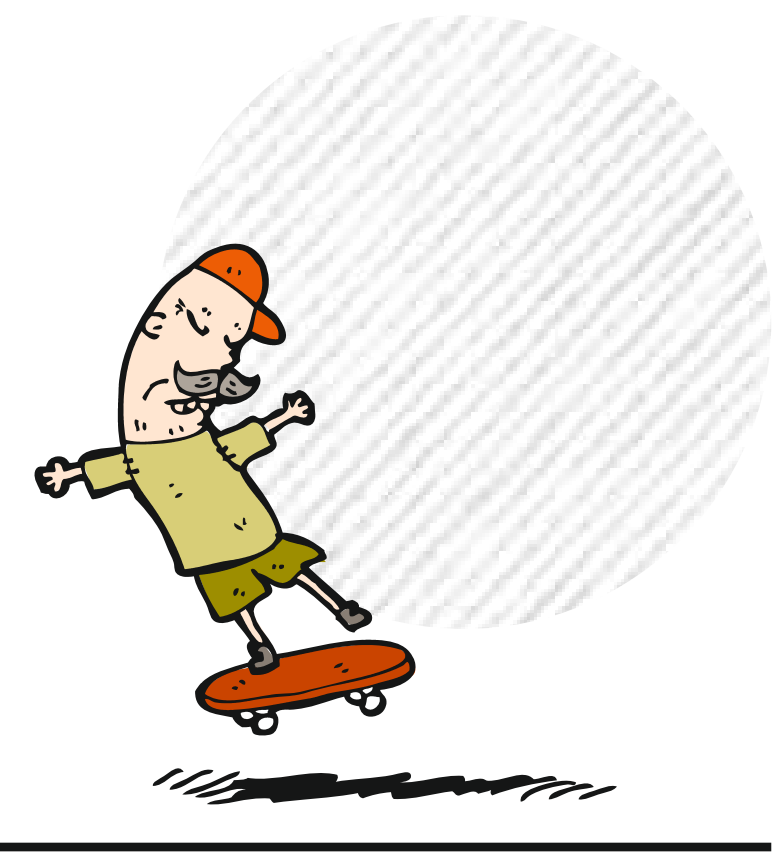

Radio Shack's 2014 Super Bowl ad played at self-parody when it showed a Radio Shack store clerk putting down the phone and telling his colleague, "The '80s called. They want their store back." The ad went on to announce a new store design, but the 3 million YouTube views in three weeks likely were driven more by enjoyment of the self-mockery than by admiration for the new design. In fact, immediately following the airing of the Super Bowl ad and its subsequent success on YouTube, Radio Shack announced the shuttering of numerous stores, following a loss in 2013.

\section{Game instructions for brands playing the social media} game /// Play can refer to the conduct of a game with winners and losers, as we suggest it does in the first of our forms of play, when marketers defeat the consumer's wish to be left alone. It can refer to the collaboration between players to achieve - if not exactly a common purpose - at least separate purposes with joint resources. Or it can refer to conduct that bemuses and befuddles, leaving no one, perhaps not even the marketer, completely sure what the relationship will be between marketer and consumer when it is all over, except that the marketer has gained visibility. So, are there any rules to lean on for playing these games successfully?
$>$ Lighten up a little /// One important element of playing games is fun. Dead-serious planning of social media interactions is a contradiction in terms. Marketing has, for a century, been a deliberate business, with goals and the corresponding campaigns to achieve them. For brands that want to enter, it may be time to lighten up a little.

$>$ No risk, no result /// It is apparent that people want to play with the brand, and brands must therefore decide if they want to actively invite participation and surrender to whatever form consumer play may take. However, they should be prepared for surprising turns. Attention and consumer engagement are the prizes at stake for taking the venture, awards that are increasingly difficult to gain with more traditional communication campaigns.

$>$ Rule out the rules /// A good deal of charm can be generated by new forms of play and generous interpretations of its rules. As long as it does not involve trickery, much will be forgiven. Creativity and flexibility in the conception and handling of single episodes will help to maintain the attraction and success of this alternative form of consumer communication.

I. 